\title{
THE CURRENT TASKS OF TRAINING PERSONNEL FOR THE INVESTIGATIVE BODIES AT THE MILITARY-TECHNICAL INSTITUTE OF THE NATIONAL GUARD OF THE REPUBLIC OF UZBEKISTAN
}

\author{
Abdumutal Karimovich Zakurlaev \\ Specialized branch of Tashkent State University of Law, \\ Associate Professor at the department Criminal-legal subjects, \\ Doctor of Law, \\ Tashkent, \\ Republic of Uzbekistan
}

Article D0I: https://doi.org/10.36713/epra3912

\begin{abstract}
The article deals with the current tasks of training personnel for the investigative bodies at the Military-Technical Institute of the National Guard of the Republic of Uzbekistan and ensuring the implementation of these tasks were analyzed by the helping sources and literatures as well.
\end{abstract}

KEY WORDS: Republic of Uzbekistan, National Guard, inquiry bodies, personnel, state bodies, criminal case, state security.

\section{INTRODUCTION}

Consistent implementation of the principle of separation of powers enshrined in the Constitution of the Republic of Uzbekistan, the formation of an effective system of checks and balances between the authorities, the creation of a mechanism to ensure clear and uniform implementation of powers and control functions of central and local government. President of the Republic of Uzbekistan Shavkat Mirziyoyev commented on the work done in this direction: "It is no coincidence that we pay special attention to the radical reform of the judiciary. It is no coincidence that the protection of human rights enshrined in our Constitution is directly related to the practical results of these reforms"[1]. In accordance with Section 9 of the Code of Criminal Procedure of the Republic of Uzbekistan, the pre-trial stage includes the initiation of a criminal case, inquiry and preliminary investigation.

\section{METHODS}

Ensuring the security of the individual, society and the state, in turn, increases the relevance of issues of public order and security for the countries of the world today. At the same time, the growing threats to law enforcement in cities and public places required a review of security mechanisms in Uzbekistan, a critical analysis of the means, methods and tasks of government agencies. Various measures are being taken around the world to effectively address these problems and ensure internal security. After all, ensuring the internal security of the country depends on the smooth functioning of government agencies, the well-being of the population, the functioning of public institutions.

\section{RESULTS AND DISCUSSIONS}

Among the activities carried out to ensure internal security in the world, these tasks are entrusted to various specially formed or operating armed and law enforcement agencies, the development of the legal framework for these bodies, the improvement of tactics or strategies of their principles.

The study of the experience of foreign countries in the field of internal security shows that in Russia these tasks are performed by the Federal 
Service of the National Guard (Russian Guard), the Corps of Corps in Italy, the Turkish Gendarmerie in Turkey, the National Guard in the United States.

For this purpose, in September 2017, the National Guard of the Republic of Uzbekistan was established. The fact that the National Guard has a unique structure, structure, management, methods of training and a unique approach to the performance of its duties allows it to operate in both military and civil relations. The National Guard plays an important role in the system of law and order and public safety in the state and society.

The National Guard of the Republic of Uzbekistan is a military and law enforcement body within the system of executive power of the Republic of Uzbekistan, which performs specific tasks to ensure the national security of our country. Military servicemen (employees) of the National Guard have a military (special) rank, unlike employees of other government agencies, and have the authority to use physical force, special means and firearms to ensure public order and safety in order to perform the tasks assigned to them by law.

The main goal of the large-scale reforms being carried out in our country today is to achieve stability, peace and tranquility in society, the welfare of the people by ensuring the external and internal security of the state.

President of the Republic of Uzbekistan Shavkat Mirziyoyev instructed the National Guard to submit a proposal to the National Guard to conduct an investigation and inquiry into two types of crimes at an enlarged meeting of the Security Council on January 10, 2019. and means that the performance of honorable duties is entrusted. Ensuring the fulfillment of these tasks requires the National Guard personnel to have modern knowledge, advanced methods of pre-investigation investigation and inquiry, and the ability to use modern technical means.

In the Action Strategy for the five priority areas of development of the Republic of Uzbekistan for 2017-2021 [2], the expansion of guarantees of reliable protection of the rights and freedoms of citizens, increasing their access to justice, efficiency and quality of judicial proceedings are among the most important judicial reforms. identified as important trends. The fulfillment of these tasks requires the adoption of certain measures to accelerate the judicial process set out in the Universal Declaration of Human Rights, the International Covenant on Civil and Political Rights and to implement the idea of "Human Rights - the highest value" enshrined in the Constitution. requires that it be done.

President of the Republic of Uzbekistan Shavkat Mirziyoyev commented on the work done in this direction: "It is no coincidence that we pay special attention to the radical reform of the judiciary. It is no coincidence that the protection of human rights enshrined in our Constitution is directly related to the practical results of these reforms"[3]. There are a number of legal mechanisms that ensure the achievement of the objectives of criminal proceedings during criminal proceedings, which determine the order, form and content of criminal proceedings.

According to the Law of the Republic of Uzbekistan "On amendments and additions to some legislative acts of the Republic of Uzbekistan in connection with the improvement of the institute of inquiry" dated September 6, 2017 No LRUz-442 [4], the essence of the institute of inquiry was radically changed. and it was directly shown that the inquiry was a form of preliminary investigation.

Inquiry is the procedural activity of bodies and officials referred to in Article 38 of the Code of Criminal Procedure in criminal cases initiated in accordance with the rules of determining their jurisdiction in accordance with the law. The procedural nature of the inquiry is set out in Chapter 461, Articles 3811-38117 of the Code of Criminal Procedure, according to which inquiry bodies collect and store evidence within one month on the offenses set forth in paragraphs 2-3 of Article 15 of the Criminal Code; the arrest of suspects in the commission of a crime, the provision of compensation for pecuniary damage caused by the crime, the involvement of a person as a suspect and accused, the drawing up of an indictment and the referral of the case to court.

It should be noted that as a result of judicial reforms in the country, the powers of the inquiry bodies have been expanded, including the transfer of cases on crimes under Article 661 of the Criminal Code in connection with the reconciliation of the inquirer, pre-trial investigation or amnesty act. has the power to send to the prosecutor a petition to refuse to institute criminal proceedings on the basis of the application of the same person, suspect, accused and amnesty act, or to submit a petition to the court to terminate the criminal case.

According to Article 38 of the Code of Criminal Procedure, criminal inquiries are carried out by law enforcement agencies, the Department for Combating Economic Crimes under the Prosecutor General's Office, the Bureau of Enforcement under the Prosecutor General's Office, the State Customs Committee, the National Guard and their local branches. The units are shown to be carried out by inquirers. At the same time, the scope of inquiries has been expanded and a number of new procedural powers have been granted.

It should be noted that in a short period of time a large-scale work has been done to improve the system of National Guard bodies, reorganize public order, civil safety systems and their subdivisions in the mahallas, define the scope of their tasks and 
responsibilities. At the same time, the current threats and challenges, in particular, international terrorism, religious extremism, illegal migration, human trafficking, the growing spread of ideas alien to our people among the youth, the National Guard has to address in time to prevent and eliminate them. puts new tasks.

This, in turn, requires the use of new methods of inquiry by the National Guard, close communication with the public, the widespread introduction of modern information and communication technologies in the activities of the National Guard. In order to conduct direct inquiry activities for cadets of the National Guard MilitaryTechnical Institute in the field of Criminal Procedure, Criminology, Rapid Investigation and Forensic Science, as well as training them in practical skills in these disciplines, pre-investigation and Inquiry classes cadets can undergo internships directly in the National Guard inquiry offices in units that are not yet fully formed. Therefore, this issue will have to be resolved before the cadets practice in March, as most of the practice on future inquiries will be conducted in criminal law enforcement agencies.

\section{CONCLUSION}

In our opinion, combining the theoretical knowledge of cadets with practical activities in the field of inquiry, the registration of crimes in the investigative agencies of the Investigation Department of the Ministry of Internal Affairs, as well as cooperation between investigative and inquiry bodies in the implementation of other investigative actions. will have the opportunity to meet.

At the same time, given that the practice is not yet fully formed by the inquiry bodies of the National Guard, there would be a certain opportunity for them to study in practice the process of development of this institution, the process of documentation in the elimination of offenses in public places.

\section{REFERENCES}

1. The Constitution is a free and prosperous life, a solid foundation for the further development of our country // Speech by President Shavkat Mirziyoyev at the ceremony dedicated to the 25th anniversary of the adoption of the Constitution of the Republic of Uzbekistan // Khalk suzi. December 6, 2017.

2. Decree of the President of the Republic of Uzbekistan No. PD-4947 of February 7, 2017

3. The Constitution is a free and prosperous life, a solid foundation for the further development of our country // Speech by President Shavkat Mirziyoyev at the ceremony dedicated to the 25th anniversary of the adoption of the Constitution of the Republic of Uzbekistan. // Khalk suzi. December 6, 2017.
4. Law of the Republic of Uzbekistan No. LRUz-442 of September 6, 2017 // Collection of Legislation of the Republic of Uzbekistan, 2017, No. 36, Article 943 